\title{
The De Long Trough: a newly discovered glacial trough on the East Siberian continental margin
}

\author{
Matt O'Regan ${ }^{1,2}$, Jan Backman ${ }^{1,2}$, Natalia Barrientos ${ }^{1,2}$, Thomas M. Cronin ${ }^{3}$, Laura Gemery ${ }^{3}$, Nina Kirchner ${ }^{2,4}$, \\ Larry A. Mayer ${ }^{5}$, Johan Nilsson ${ }^{2,6}$, Riko Noormets ${ }^{7}$, Christof Pearce ${ }^{1,2,8}$, Igor Semiletov ${ }^{9,10}$, Christian Stranne $^{1,2,5}$, \\ and Martin Jakobsson ${ }^{1,2}$ \\ ${ }^{1}$ Department of Geological Sciences, Stockholm University, 10691, Stockholm, Sweden \\ ${ }^{2}$ Bolin Centre for Climate Research, Stockholm University, 10691, Stockholm, Sweden \\ ${ }^{3}$ US Geological Survey MS926A, Reston, Virginia 20192, USA \\ ${ }^{4}$ Department of Physical Geography (NG), Stockholm University, 10691, Stockholm, Sweden \\ ${ }^{5}$ Center for Coastal and Ocean Mapping, University of New Hampshire, Durham, New Hampshire 03824, USA \\ ${ }^{6}$ Department of Meteorology, Stockholm University, 10691, Stockholm, Sweden \\ ${ }^{7}$ University Centre in Svalbard (UNIS), P.O. Box 156, 9171, Longyearbyen, Svalbard, Norway \\ ${ }^{8}$ Department of Geoscience, Aarhus University, 8000, Aarhus, Denmark \\ ${ }^{9}$ Pacific Oceanological Institute, Far Eastern Branch of the Russian Academy of Sciences, 690041, Vladivostok, Russia \\ ${ }^{10}$ Tomsk National Research Polytechnic University, 634050, Tomsk, Russia
}

Correspondence to: Matt O’Regan (matt.oregan@geo.su.se)

Received: 30 March 2017 - Discussion started: 20 April 2017

Revised: 31 July 2017 - Accepted: 21 August 2017 - Published: 28 September 2017

\begin{abstract}
Ice sheets extending over parts of the East Siberian continental shelf have been proposed for the last glacial period and during the larger Pleistocene glaciations. The sparse data available over this sector of the Arctic Ocean have left the timing, extent and even existence of these ice sheets largely unresolved. Here we present new geophysical mapping and sediment coring data from the East Siberian shelf and slope collected during the 2014 SWERUS-C3 expedition (SWERUS-C3: Swedish - Russian - US Arctic Ocean Investigation of Climate-Cryosphere-Carbon Interactions). The multibeam bathymetry and chirp sub-bottom profiles reveal a set of glacial landforms that include grounding zone formations along the outer continental shelf, seaward of which lies a $>65 \mathrm{~m}$ thick sequence of glacio-genic debris flows. The glacial landforms are interpreted to lie at the seaward end of a glacial trough - the first to be reported on the East Siberian margin, here referred to as the De Long Trough because of its location due north of the De Long Islands. Stratigraphy and dating of sediment cores show that a drape of acoustically laminated sediments covering the glacial deposits is older than $\sim 50 \mathrm{cal} \mathrm{kyr} \mathrm{BP}$. This provides direct evidence for extensive glacial activity on the Siberian shelf that
\end{abstract}

predates the Last Glacial Maximum and most likely occurred during the Saalian (Marine Isotope Stage (MIS) 6).

\section{Introduction}

The glacial history of the Siberian continental shelf of the East Siberian Sea is poorly known and marine geological and geophysical data from this region are scarce. Most of the area is shallower than $120 \mathrm{~m}$, implying that it was exposed during the sea level low stand of the Last Glacial Maximum (LGM) and the larger glaciations following the mid-Pleistocene transition (Lambeck et al., 2014; Rohling et al., 2014), even considering glacial isostatic adjustments (Klemann et al., 2015) (Fig. 1). One consequence of the shallowness of the East Siberian shelf is that submarine glacial landforms, signifying the presence of an ice sheet (Dowdeswell et al., 2016), may have been eroded during regressive and transgressive cycles.

On formerly glaciated margins, areas of fast-streaming glacial ice are recognized by the presence of glacially excavated cross-shelf troughs (CSTs) (Batchelor and Dowdeswell, 2014). CSTs and their sedimentary archives 


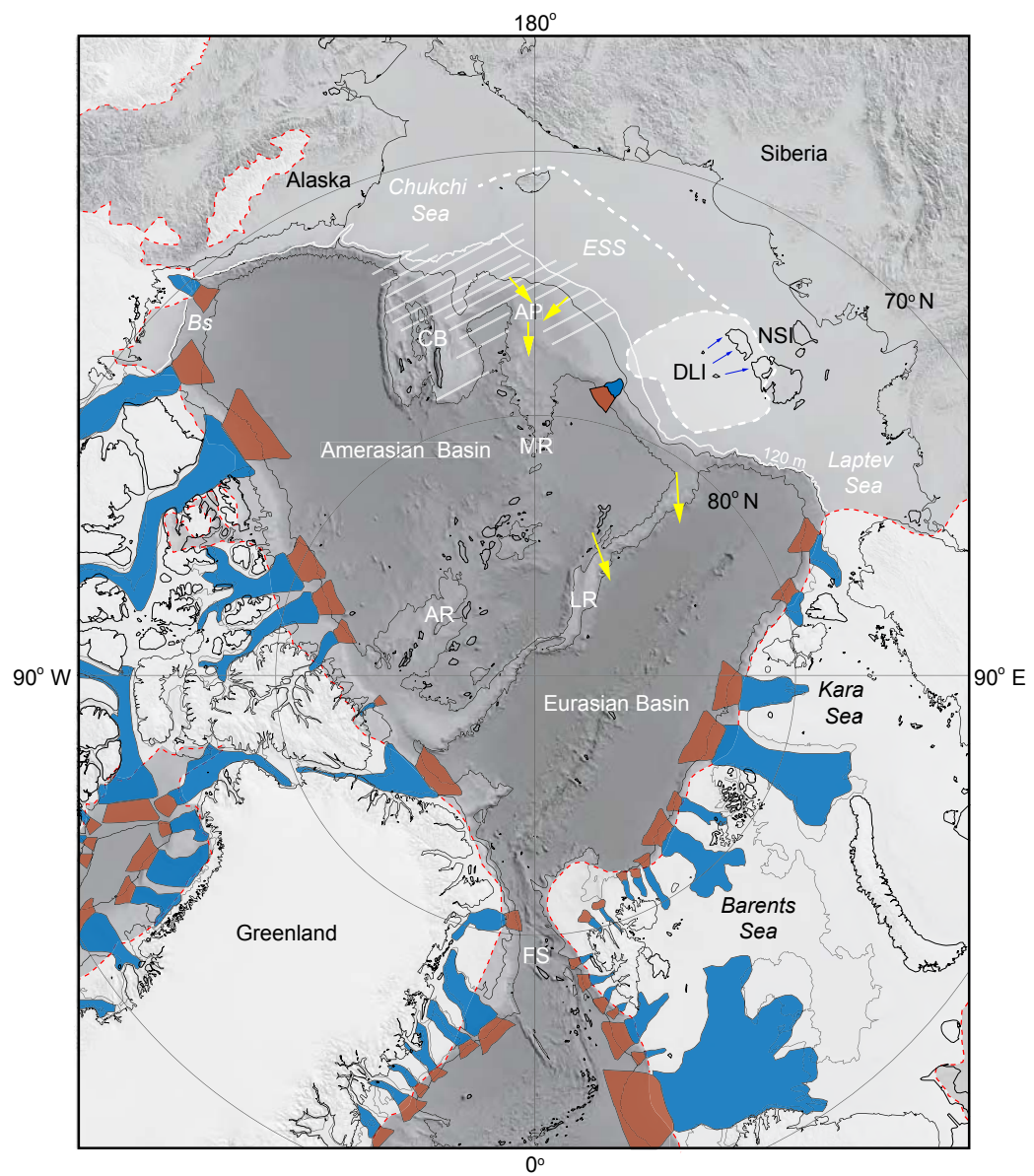

Figure 1. Map of the Arctic Ocean showing the maximum extent of Quaternary glaciations (red dashed line) (Jakobsson et al., 2014). The $120 \mathrm{~m}$ isobath is highlighted across the Siberian, Chukchi and Beaufort seas to highlight the potential extent of exposed land during the global eustatic low stand of the LGM. Yellow arrows indicate the direction of ice flow inferred from the orientation of glacial landforms on the deep Arctic seafloor (Jakobsson et al., 2016). Glacial extents and flow directions around the New Siberian Islands (NSI) and De Long Islands (DLI) are redrawn from Basilyan et al. (2008). Dashed lines across the East Siberian shelf and hatching on the Chukchi Borderland (CB) indicate areas of probable glacial ice in the late Quaternary (Jakobsson et al., 2014). Known glacially excavated cross-shelf troughs (blue) and trough mouth fans (brown) are redrawn from Batchelor and Dowdeswell (2014) - the exception is the single trough on the East Siberian shelf, which is described in this paper. AP - Arlis Plateau; AR - Alpha Ridge; BS - Beaufort Sea; FS - Fram Strait; MR - Mendeleev Ridge; LR - Lomonosov Ridge.

are diagnostic features for the presence of former ice sheets (Dowdeswell et al., 2016) and extensively used to reconstruct ice sheet dynamics (Polyak et al., 1997; Anderson et al., 2002; Winsborrow, et al., 2010; Jakobsson et al., 2012a; Kirshner et al., 2012; Hogan et al., 2010, 2016). Their association with fast-streaming ice is supported by the common presence of mega-scale glacial lineations (MSGL) within them (Clark, 1993; Stokes and Clark, 2002; Ó Cofaigh et al., 2002; Ottesen et al., 2005; King et al., 2009). MSGL are stream-lined, trough-parallel sedimentary landforms that range from kilometers to tens of kilometers in length (Stokes and Clark, 2002) and have been observed forming beneath active ice streams in West Antarctica (King et al., 2009). Within a CST, large asymmetrical sedimentary wedges oriented transversely to the ice flow direction mark stillstands in the streaming-ice and are known as grounding zone wedges (GZWs) (Batchelor and Dowdeswell, 2015). They are formed by high rates of subglacial sediment delivery to the grounding zone and can occur at vertical or lateral pinning points in the trough bathymetry or near the shelf break (Batchelor and Dowdeswell, 2015). MSGL are often found beneath and/or on top of GZWs (Jakobsson et al., 2012a), which supports the interpretation that GZW formation occurs during stillstands of fast-streaming ice. GZWs typically have much larger length-to-height ratios than terminal moraines, which are more commonly found in inter-ice stream regions on glaciated margins and are associated with slower ice flow velocities (Ottesen and Dowdeswell, 2009; Batchelor and Dowdeswell, 2015; Dowdeswell et al., 2016). 
Ice streams within CSTs terminate in a calving front where large volumes of icebergs are discharged into the ocean or feed into ice shelves. Seaward of the shelf break, large volumes of subglacial sediments are discharged onto the slope in front of CSTs and form bathymetrically prominent trough mouth fans (TMFs) (Ó Cofaigh et al., 2003; Batchelor and Dowdeswell, 2014). These are composed of stacked glaciogenic debris flows, deposited while the ice was at or near the shelf break and are interbedded with ice-distal or open-water marine sediments (Laberg and Vorren, 1995; Elverhøi et al. 1997; Taylor et al., 2002). TMF development is more prominent in front of CSTs that have hosted repeated ice stream activity across numerous glacial cycles and where sediment is delivered to relatively shallow continental slopes (Batchelor et al., 2014).

Twenty glacially excavated troughs emptying directly into the Arctic Ocean are identified in existing bathymetric and seismic data from north of Fram Strait (Batchelor and Dowdeswell, 2014) (Fig. 1). Several of these can be traced back into tributary fjords on adjacent landmasses, or towards the center of former ice sheets, and are particularly pronounced along the Barents-Kara and North American margins (Batchelor and Dowdeswell, 2014; Jakobsson, 2016) (Fig. 1). By contrast, the shallow shelves of the East Siberian and Chukchi seas lack any identified CSTs. Despite the absence of these diagnostic features, ice sheets extending over parts of the East Siberian continental shelf have been proposed in literature during the LGM (Toll, 1897; Hughes et al., 1977; Grosswald, 1990), MIS 6 (Basilyan et al., 2008, 2010; Jakobsson et al., 2016) and the larger Pleistocene glaciations that followed the mid-Pleistocene transition (Colleoni et al., 2016; Niessen et al., 2013).

The existence of an ice sheet on the New Siberian Islands was first proposed by Toll (1897) based on the widespread occurrence of ice wedges, which he interpreted as relict glacial ice. Although ice wedges are today known to be formed in permafrost by the refreezing of water flowing into cracks, glacio-tectonized Cretaceous and Cenozoic sediments on the New Siberian Islands do contain thick inclusions of ice interpreted to originate from an ice sheet and are overlain by conformable Quaternary sediments (Basilyan et al., 2008, 2010). The orientation of the glacio-tectonic features indicates that glacial ice on the New Siberian Islands flowed from a north-northeast direction and likely nucleated over the De Long Islands, where small glaciers remain today (Basilyan et al., 2008) (Fig. 1). Uranium-thorium $\left({ }^{230} \mathrm{Th} /{ }^{234} \mathrm{U}\right)$ dating on mollusk shells in sediments overlying the glacial deposits made Basilyan et al. (2010) conclude that the glaciation may have been centered around $135 \mathrm{ka}$, during MIS 6.

Another line of evidence for glacial ice on the Siberian continental shelf is the presence and orientation of glaciogenic features and sedimentary deposits mapped on the seafloor in the adjacent Arctic Basin. These glacial features are mapped on the lower slope of the East Siberian Sea and on the crest of shallower ridges and plateaus of the Arctic Ocean (Niessen et al., 2013; Jakobsson et al., 2016). Streamlined glacial lineations on the seabed of the Arlis Plateau and the base of the East Siberian continental slope have orientations that indicate ice flow from the East Siberian shelf (Niessen et al., 2013; Jakobsson et al., 2016) (Fig. 1). Niessen et al. (2013) speculate that the modern water depths of these features, ranging between about $900 \mathrm{~m}$ and $1200 \mathrm{~m}$ below sea level (m b.s.l.), imply an ice thickness on the East Siberian continental shelf of up to $2 \mathrm{~km}$. Glacial lineations also exist on a heavily ice-scoured crest of the southern Lomonosov Ridge $\left(81^{\circ} \mathrm{N} 143^{\circ} \mathrm{E}\right)$, where, together with a gently sloping stoss side towards the Makarov Basin and a steep lee side facing the Amundsen Basin, clearly indicate grounded glacial ice flowing from the East Siberian shelf (Jakobsson et al., 2016) (Fig. 1). Combined with the orientations of glacial features on the Chukchi Borderland (Dove et al., 2014), Alaskan Beaufort Slope (Engels et al., 2008) and central Lomonosov Ridge (Jakobsson et al., 2010, 2016), it is suggested that large ice shelves in the Amerasian Arctic existed during past glacial periods and were fed from ice discharging from the East Siberian shelf and North America (Jakobsson et al., 2010). Recent mapping on the Lomonosov Ridge led Jakobsson et al. (2016) to propose that an ice shelf was not limited to the Amerasian Arctic Ocean and instead covered the entire central Arctic Ocean. Marine sediments atop the mapped glacial features in the central Arctic Ocean have consistently been dated to MIS 5.5, implying that the large central Arctic Ocean ice shelf existed during MIS 6 (Jakobsson et al., 2010, 2016). However, marine-based glaciers large enough to ground on the Chukchi Borderland may have existed after MIS 5.5 (Polyak et al., 2007), feeding a thinner ice shelf that covered parts of the West and central Arctic (Jakobsson et al., 2014).

Despite the mounting evidence for glacial ice on the East Siberian shelf, our ability to define its extent and timing remains limited. In part this is due to the lack of glacial morphology on the shelf that could be used to link the terrestrial observations with marine mapping results in deeper water settings of the Arctic Ocean. However, the sparse data availability across the East Siberian shelf implies that the absence of known submarine geomorphological features does not preclude their existence. Here we present new geophysical and sedimentological evidence for a glacial trough north of the De Long and New Siberian Islands on the outer margin of the East Siberian shelf. The trough was most likely occupied by glacial ice during MIS 6 and certainly free from glacial ice during the LGM.

\section{Methods}

\subsection{Expedition}

The data presented in this paper were acquired on Leg 2 of the SWERUS-C3 2014 Expedition on IB Oden, which de- 


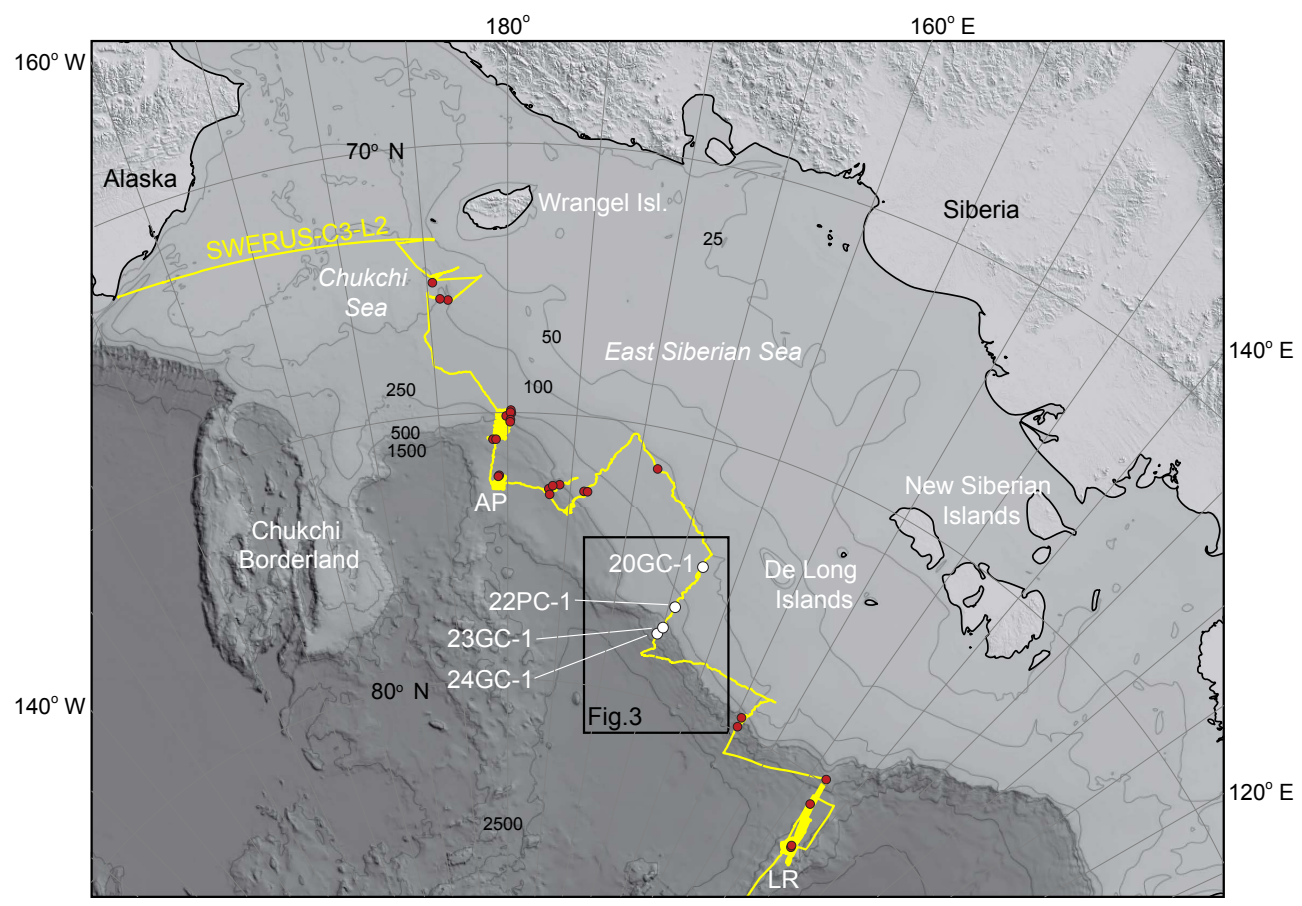

Figure 2. Ship track and coring sites during SWERUS-C3-L2. Location of the geophysical data and sediment cores discussed in this paper is highlighted.

parted 21 August from Barrow, Alaska, and ended 3 October in Tromsø, Norway (Fig. 2). The data include multibeam bathymetry, chirp sub-bottom profiles and analyses of sediment cores collected along a $225 \mathrm{~km}$ long downslope transect spanning water depths of 115 to $1800 \mathrm{~m}$ b.s.l. (Fig. 3).

\subsection{Geophysical mapping}

A brief summary of the geophysical mapping methods during the SWERUS-C3 expedition is included here; further details are described in Jakobsson et al. (2016). Multibeam bathymetry and sub-bottom profiles were collected with the Kongsberg EM $122\left(12 \mathrm{kHz}, 1^{\circ} \times 1^{\circ}\right)$ multibeam and integrated SBP $120\left(2-7 \mathrm{kHz}, 3^{\circ} \times 3^{\circ}\right)$ chirp sonar installed on IB Oden. This system has a Seatex Seapath 330 unit for the integration of GPS navigation, heading and attitude. Temperature and salinity data from CTD (conductivity, temperature, depth) stations and regular XBT (expendable bathythermograph) casts were used to calculate sound speed profiles for the calibration of the multibeam. Multibeam bathymetry was post-processed using a combination of the Caris and Fledermaus-QPS software. Sub-bottom profiles were acquired using a $2.5-7 \mathrm{kHz}$ chirp pulse. The chirp sonar profiles were post-processed and interpreted using a combination of the open-source software OpendTect created by dGB Earth Sciences and tools provided by the Geological Survey of Canada (courtesy Bob Courtney).

\subsection{Sediment cores}

Four sediment cores (inner diameter of $100 \mathrm{~mm}$ ) are presented in this study (Table 1). They were collected using either a piston (PC) or gravity (GC) corer, both rigged with a $1360 \mathrm{~kg}$ core head. The unsplit sediment cores were allowed to equilibrate to room temperature $\left(20^{\circ} \mathrm{C}\right)$ and logged shipboard on a Multi-Sensor Core Logger (MSCL). Bulk density, compressional-wave velocity ( $p$ wave) and magnetic susceptibility (Bartington loop sensor) were measured at a downcore resolution of $1 \mathrm{~cm}$. The cores were split and described shipboard and imaged using a digital line-scanning camera. The undrained shear strength $\left(S_{\mathrm{U}}\right)$ of the sediments was measured using a CONTROLS-group liquid limit penetrometer (fall cone). The fall cone test was performed according to ISO-TS-17892-6 (Swedish Standards Institute) at a downcore resolution of approximately $30 \mathrm{~cm}$. For most measurements a $60^{\circ} / 82 \mathrm{~g}$ cone was used, but in some instances a heavier weight $\left(60^{\circ} / 112 \mathrm{~g}\right)$ or narrower cone $\left(30^{\circ} / 62 \mathrm{~g}\right)$ was used to achieve the recommended cone penetration depth of 4-20 mm.

The undrained shear strength was calculated using the cone geometry, weight and penetration:

$S_{\mathrm{U}}=K g \frac{Q}{h^{2}}$,

where $K$ is a cone-dependent constant ( 0.8 for the $30^{\circ}$ cone and 0.27 for the $60^{\circ}$ cone), $Q$ is the cone weight (g), $g$ the 


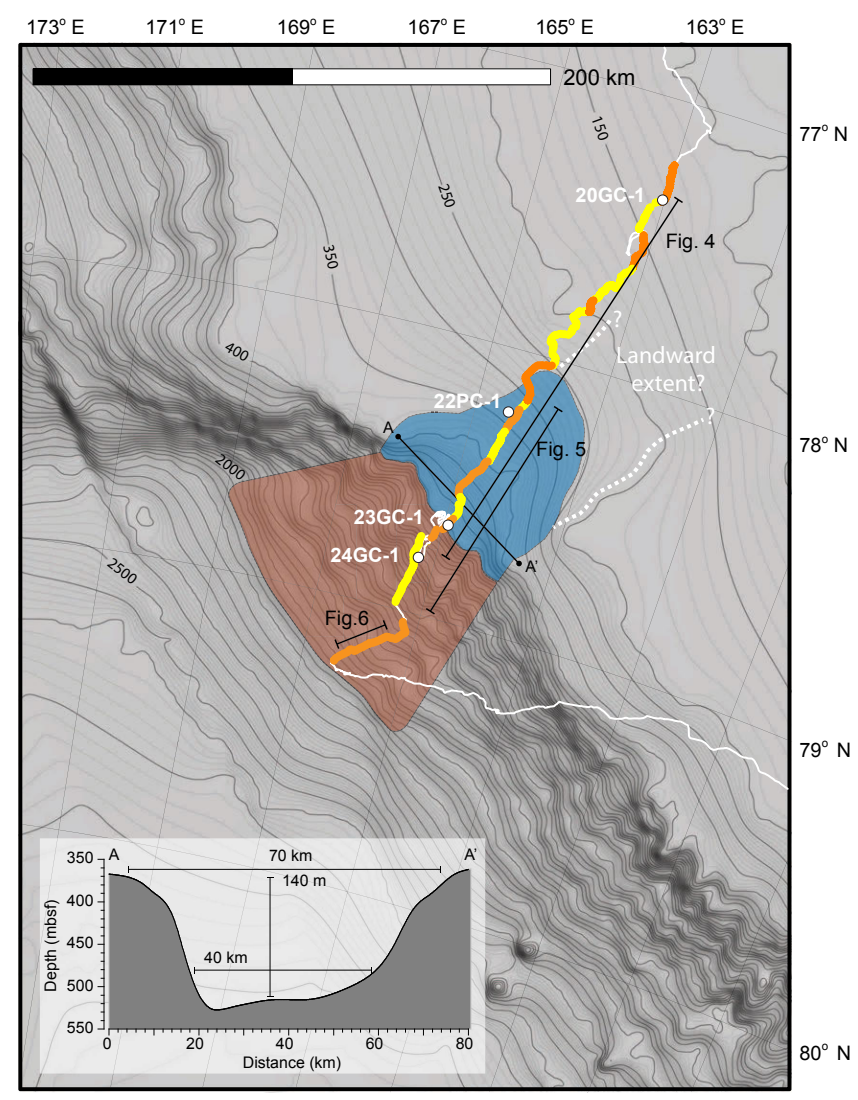

Figure 3. Detail of study area showing ship track with the yellow and orange lines indicating portions of the chirp sub-bottom data presented in Figs. 4 and 5. Locations of sediment cores discussed in the text are shown. Blue and brown shading represents the bounds of the glacial trough and trough mouth fan deposits (respectively) as interpreted from the geophysical data collected during SWERUSC3-L2. Bathymetry from IBCAO (Jakobsson et al., 2012b), with $50 \mathrm{~m}$ major contour intervals.

Table 1. Location and length of sediment cores discussed in this paper.

\begin{tabular}{lllll}
\hline Core & $\begin{array}{l}\text { Depth } \\
(\mathrm{m} b . s . f .)\end{array}$ & $\begin{array}{l}\text { Length } \\
(\mathrm{m})\end{array}$ & Latitude & Longitude \\
\hline 20-GC1 & 115 & 0.83 & $77^{\circ} 21.5^{\prime} \mathrm{N}$ & $163^{\circ} 2.0^{\prime} \mathrm{E}$ \\
$22-\mathrm{PC} 1$ & 364 & 6.49 & $78^{\circ} 13.4^{\prime} \mathrm{N}$ & $164^{\circ} 27.7^{\prime} \mathrm{E}$ \\
$23-\mathrm{GC} 1$ & 508 & 4.06 & $78^{\circ} 39.7^{\prime} \mathrm{N}$ & $165^{\circ} 0.9^{\prime} \mathrm{E}$ \\
$24-\mathrm{GC} 1$ & 964 & 4.05 & $78^{\circ} 47.8^{\prime} \mathrm{N}$ & $165^{\circ} 22.0^{\prime} \mathrm{E}$ \\
\hline
\end{tabular}

acceleration due to gravity $\left(9.81 \mathrm{~m} \mathrm{~s}^{-2}\right)$ and $h$ the cone penetration $(\mathrm{mm})$.

Shore-based measurements on the split cores were conducted at the Department of Geological Sciences, Stockholm University. These included additional magnetic susceptibility measurements, grain size and $\mathrm{x}$-ray fluorescence (XRF)-core scanning. The magnetic susceptibility was remeasured on the MSCL using a Bartington point sensor. Compared to the loop sensor measurements on the whole core, the point sensor provides superior horizontal resolution (lower effective sensor length) but only measures the susceptibility of sediments in the upper few millimeters from the split core surface.

Sediment grain size ( $2 \mu \mathrm{m}$ to $2 \mathrm{~mm})$ was measured at a $5 \mathrm{~cm}$ downcore resolution using a Malvern Mastersizer 3000 laser diffraction particle size analyzer. Wet samples were immersed in a dispersing agent $(<10 \%$ sodiumhexametaphosphate solution) and placed in an ultrasonic bath to ensure full particle disaggregation before analyses. The mean grain size and sorting were calculated using the geometric method of moments (Blott and Pye, 2001).

Elemental abundances were measured on the archive half of the split cores using a Cox Analytical Systems Itrax XRFcore scanner core scanner. Analyses were made with a Mo tube set to $55 \mathrm{kV}$ and $50 \mathrm{~mA}$, a step size of $2 \mathrm{~mm}$ and a counting time of $20 \mathrm{~s}$. The data were normalized by the incoherent + coherent scattering, and the ratio of $\mathrm{Ca} / \mathrm{Ti}$ was used to help stratigraphically correlate the sediment cores.

\subsection{Dating}

Accelerator mass spectrometry (AMS) radiocarbon measurements were made on samples containing the planktonic foraminifer Neogloboquadrina pachyderma, mixed benthic foraminifera or mollusk shells. These were performed at either the National Ocean Sciences Accelerator Mass Spectrometry (NOSAMS) facility at Woods Hole Oceanographic Institution, Massachusetts, or the Lund University Radiocarbon Dating Laboratory (Lu), Sweden. Six radiocarbon ages were obtained from the core catcher of 20-GC1, and single range finding ages were obtained from both $23-\mathrm{GC} 1$ and $24-$ GC1 (Table 2).

\section{Results}

\subsection{Sub-bottom stratigraphy}

The sub-bottom stratigraphy from the outer shelf 20-GC1 $\left(77^{\circ} 21.5^{\prime} \mathrm{N}, 163^{\circ} 2.0^{\prime} \mathrm{E}\right)$ to the shelf break is divided into six acoustic units (Fig. 4). Unit 1 is a thin, discontinuous, largely incoherent veneer of sediments with a sharp basal contact (R1) on the shallow shelf $(<150 \mathrm{mb}$ b.s.l.) that can be traced into water depths of between 260 and $300 \mathrm{mb}$ b.s.l. Above $260 \mathrm{~m}$ b.s.l., it is underlain by Unit 2, mostly composed of horizontally layered or dipping and truncated reflection packages interspersed with intervals of acoustically transparent material (Fig. 4). The base of Unit 2 is never imaged in the sub-bottom data, but on the shallowest regions of the survey area, it extends more than 50-60 m below the seafloor (m b.s.f.). Between 260 and 300 m b.s.l., Unit 1 transitions into a coherent and laterally continuous acoustically layered sequence (Unit 3) (Fig. 4). The R1 reflector is no longer distinguishable. 


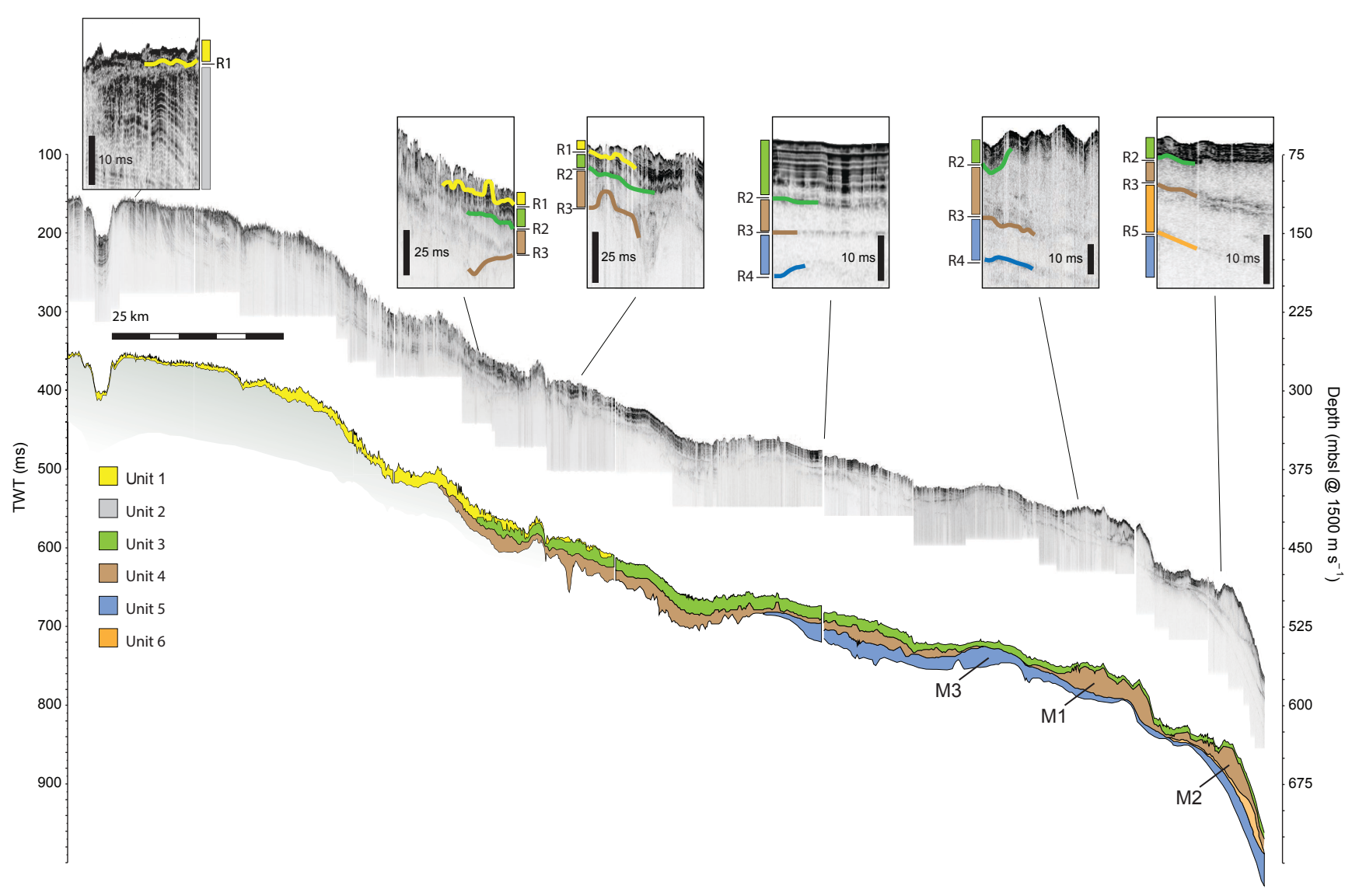

Figure 4. Composite chirp sub-bottom profile from the shallow East Siberian shelf to the shelf break at $\sim 500 \mathrm{~m}$ b.s.l. Depths are interpreted using a constant seawater velocity of $1500 \mathrm{~m} \mathrm{~s}^{-1}$. An interpreted profile with six acoustic units is shown below the sub-bottom data; it is offset by $200 \mathrm{~ms}$ TWT (two-way travel time) from the true depth. Details of the acoustic units and traced reflectors are shown in detailed images. Acoustic Unit 1 transitions into an acoustically laminated and undisturbed drape of sediment (Unit 3) below $\sim 260 \mathrm{mb}$.s.1. The location of the profile is shown in Fig. 3.

The base of Unit 3 is defined by a hummocky reflector (R2) that overlies two acoustically transparent facies (Units 4 and 5). The thickness of Unit 4 varies considerably along the track line, in places infilling $\mathrm{v}$-shaped wedges, and near the shelf break, thickening into two prominent sedimentary deposits, here referred to as mounds M1 and M2 (Figs. 4, 5). Although the exact lengths cannot be determined because of the orientation of the ship track, M1 is $\sim 10-15 \mathrm{~km}$ long and at its maximum height approaches $30 \mathrm{~ms}$ TWT (24-27 m using a $p$ wave velocity of $1600-1800 \mathrm{~m} \mathrm{~s}^{-1}$ ). M2 is smaller ( 5-10 km long) but attains a similar thickness to M1.

Units 4 and 5 are similar in appearance but separated by an often strong and planar reflector (R3), which exists seaward of $360 \mathrm{~m}$ b.s.l. (480 ms TWT). A third sedimentary deposition, mound M3, is recognized within Unit 4 and lies landward of M1 and M2 within seismic Unit 5 (Figs. 4, 5). It is $\sim 10-15 \mathrm{~km}$ long and has a thickness of $35 \mathrm{~ms}$ TWTW (28$32 \mathrm{~m}$ using a $p$ wave velocity of $1600-1800 \mathrm{~m} \mathrm{~s}^{-1}$ ). Superposition of acoustic units interpreted from the sub-bottom data indicates that M3 is the oldest of these features (Figs. 4, 5).
All of the sedimentary mounds are composed of the acoustically chaotic to transparent material. M1 and M2 appear asymmetric, with steeper seaward-facing slopes.

At the shelf break, the base of units 4 and 5 are separated by a distinct acoustically transparent, wedge-shaped sediment package (Unit 6) whose upper boundary is defined by R3 and whose lower boundary is defined by R5 (Figs. 4, 5). Seaward of the shelf break, only the uppermost acoustically laminated unit (Unit 3) can be laterally traced (Fig. 5). It overlies a complex sequence of strong undulating, discontinuous acoustically laminated sections, interspersed with thicker acoustically transparent intervals (Fig. 6). This sequence extends to the maximum depth of the surveyed area (> $2000 \mathrm{~m}$ b.s.l.).

\subsection{Multibeam bathymetry}

The seabed above water depths of $280-320 \mathrm{~m}$ b.s.l. is heavily ice scoured. Below $320 \mathrm{~m}$ b.s.l., iceberg scouring becomes less prevalent. With the exception of the iceberg scours, there 


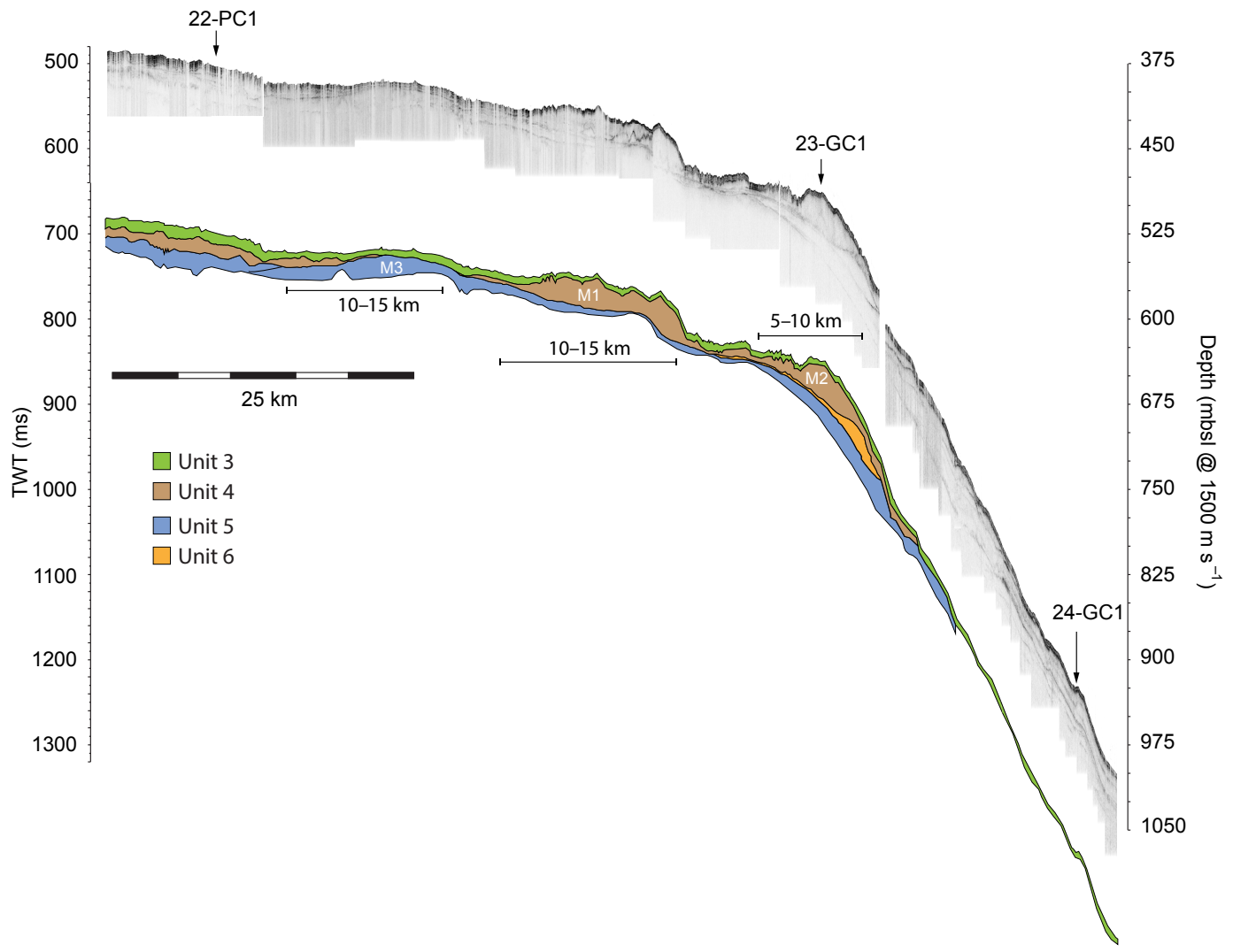

Figure 5. Location of sediment cores 22-PC1, 23-GC1 and 24-GC1 along the composite chirp sub-bottom profile. The interpreted profile is offset by $200 \mathrm{~ms}$ TWT from the true depth. The location of the profile is shown in Fig. 3.

Table 2. Radiocarbon dates and calibrations from sediment cores 20-GC1, 23-GC1 and 24-GC1. All dates were calibrated with the Marine13 calibration curve (Reimer et al., 2013), with $\Delta R=50 \pm 100$ years for 20-GC1 (Cronin et al., 2017) and $\Delta R=0$ years for 23-GC1 and 24GC1.

\begin{tabular}{|c|c|c|c|c|c|c|c|c|}
\hline $\begin{array}{l}\text { Sample } \\
\text { (core, section, interval) }\end{array}$ & $\begin{array}{r}\text { Mid-depth } \\
\text { (m b.s.f.) }\end{array}$ & Lab ID & Material & $\begin{array}{r}{ }^{14} \mathrm{C} \text { age } \\
\text { (years } \mathrm{BP} \text { ) }\end{array}$ & Error & $\begin{array}{r}\mathrm{Cal} 2 \sigma \\
\text { max. age } \\
(\text { cal years BP) }\end{array}$ & $\begin{array}{r}\text { Cal } 2 \sigma \\
\text { min. age } \\
\text { (cal years BP) }\end{array}$ & $\begin{array}{r}\text { Median } \\
\text { cal. age } \\
\text { (cal years BP) }\end{array}$ \\
\hline 20-GC1, CC, 2-4 cm & 0.56 & LuS11284 & $\begin{array}{l}\text { Mixed benthic } \\
\text { foraminifera: Elphid- } \\
\text { ium spp., Pyrgo sp., } \\
\text { Islandiella teretis }\end{array}$ & 10725 & 65 & 12511 & 11468 & 12044 \\
\hline $20-\mathrm{GC} 1, \mathrm{CC}, 18-20 \mathrm{~cm}$ & 0.72 & NOSAMS131224 & Mollusk & 11050 & 30 & 12720 & 12163 & 12521 \\
\hline $20-\mathrm{GC} 1, \mathrm{CC}, 20-22 \mathrm{~cm}$ & 0.74 & LuS11285 & Mollusk: Macoma sp. & 10110 & 55 & 11263 & 10715 & 11034 \\
\hline $20-\mathrm{GC} 1, \mathrm{CC}, 22-24 \mathrm{~cm}$ & 0.76 & NOSAMS131225 & Mollusk & 10050 & 40 & 11200 & 10693 & 10968 \\
\hline $20-\mathrm{GC} 1, \mathrm{CC}, 27-29 \mathrm{~cm}$ & 0.81 & LuS11286 & Mollusk: Macoma sp. & 11785 & 65 & 13439 & 12929 & 13209 \\
\hline $20-\mathrm{GC} 1, \mathrm{CC}, 27-29 \mathrm{~cm}$ & 0.81 & NOSAMS131226 & Mollusk & 10900 & 60 & 12619 & 11953 & 12318 \\
\hline $23-\mathrm{GC} 1,2,62-79 \mathrm{~cm}$ & 1.77 & Lu131228 & Mollusk & 33200 & 560 & 38500 & 35700 & 37000 \\
\hline $24-\mathrm{GC} 1,2,87-89 \mathrm{~cm}$ & 1.92 & Lu131229 & $\begin{array}{l}\text { Planktonic } \\
\text { Foraminifera, } \\
\text { N. pachyderma }\end{array}$ & 43000 & 1800 & 49800 & 43700 & 46300 \\
\hline
\end{tabular}

are no prominent morphological seafloor features distinguishable along the transect, where a single swath of multibeam bathymetry was collected (Fig. 7). Where the small survey was made in the vicinity of coring site $23-\mathrm{GC} 1$, the three sedimentary mounds identified in the sub-bottom profiles (Fig. 4) are visible as morphological seafloor expressions
(Fig. 7). The multibeam bathymetry reveals that the mounds extend laterally as far as the survey covers $(\sim 10 \mathrm{~km})$. Furthermore, it is seen in the bathymetry that the sub-bottom profiles presented in Fig. 4 cross M1 and M2 at an angle of about $45^{\circ}$, while the ship changed course when crossing M3 to follow its direction for $\sim 3.5 \mathrm{~km}$ before returning to the old 


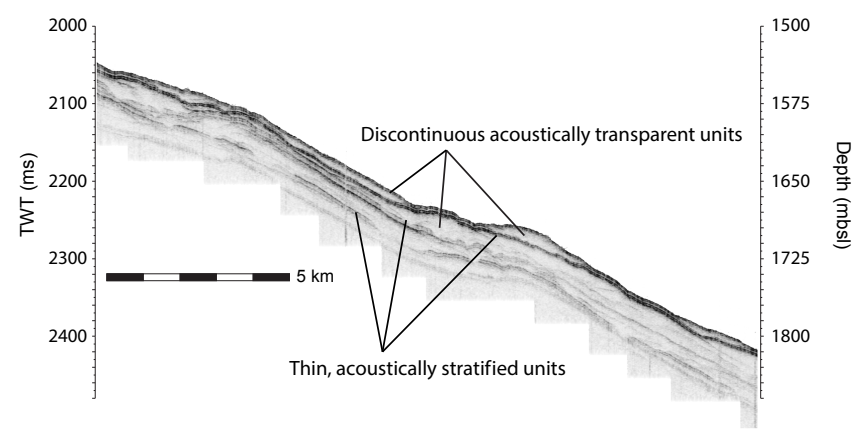

Figure 6. Representative acoustic stratigraphy of the continental slope, where a thin acoustically laminated veneer of sediments overlies a series of stacked acoustically transparent intervals. Some of the acoustically transparent intervals are laterally continuous but all exhibit substantial downslope variations in thickness. The location of the profile is shown in Fig. 3.

course. This implies that the expression of M3 likely appears more vertically subdued and laterally extensive than it is.

The bathymetry from the International Bathymetric Chart of the Arctic Ocean (IBCAO) (Jakobsson et al., 2012b) is shown as a backdrop in Fig. 7. The depth difference between the newly collected multibeam bathymetry with IB Oden and IBCAO is largest (reaching $>100 \mathrm{~m}$ ) in the area of the shelf break where M1-M3 are located.

\subsection{Sediment stratigraphy and chronology}

Three of the sediment cores presented in this study penetrated to the base of acoustic Unit 3 (22-PC1, 23-GC1 and 24-GC1), while the shallowest core (20-GC1) sampled sediments from acoustic Unit 1. The bases of 22-PC1, 23GC1 and 24GC-1 all contained a dark grey, poorly sorted sequence of coarser-grained sediments (sedimentary unit B) interpreted as a diamict (Fig. 8). The transition into this lower sedimentary unit is abrupt and is reflected by a substantial increase in sediment bulk density, compressional-wave velocity and magnetic susceptibility (Fig. 8). The undrained shear strength increases in Unit B but remains relatively low, only exceeding $15 \mathrm{kPa}$ in 23-GC1 (Fig. 8). Point and loop sensor susceptibility measurements coincide throughout sedimentary Unit A and diverge in the coarser-grained Unit B (Fig. 8). This likely reflects the presence of larger magnetic clasts irregularly distributed within the coarse grained sediments. Benthic and planktic foraminifera are found within Unit B in both 22-PC and 24-GC.

In the upper $50 \mathrm{~cm}$ of 22-PC1, 23-GC1 and 24-GC1, a less pronounced coarser-grained interval is present, again displaying higher bulk density but with no notable change in the magnetic susceptibility. Although notable, for the purpose of this paper, this interval has not been classified as a distinct sedimentary unit. Correlation between the two sedimentary units (A and B) in 22-PC1, 23-GC1 and 24-GC1 is straightforward using the grain size and physical property data (Fig. 9). It is further refined by incorporating the $\mathrm{Ca} / \mathrm{Ti}$ ratio from the XRF-scanning data (Fig. 9).

Core 20-GC1, obtained from the shallow shelf, also contained a coarser-grained, dark grey facies at its base, transitioning into lower-density and susceptibility sediments above $0.5 \mathrm{~m}$ b.s.f. Six radiocarbon dates were obtained from below $0.55 \mathrm{~m}$ b.s.f. in this core and indicate that the basal sequence is younger than $14 \mathrm{cal} \mathrm{kyr} \mathrm{BP}$ and was deposited after sea level transgression of this site following the last glacial cycle (Cronin et al., this volume). Although the base of the core has similar sedimentary characteristics to Unit $\mathrm{B}$ in 22-PC1, 23-GC1 and 24-GC1, it is not syndepositional. Radiocarbon dates from a mollusk shell in 23-GC1 (1.69-1.86 m b.s.f.) and a foraminiferal bearing interval in 24-GC1 (1.91-1.93 m b.s.f.) return ages of $33200 \pm 560$ and $43000 \pm 1800{ }^{14} \mathrm{C}$ years BP, respectively. Calibrated median ages, neglecting any additional $\Delta R$ and reported to $2 \sigma$, are $37000 \pm{ }_{1300}^{2600}$ and $46300 \pm{ }_{2600}^{3500}$ cal years BP (Table 2 ). The radiocarbon dates are consistent with the stratigraphic correlation between the cores (Fig. 9). Investigations into the occurrence of calcareous nannofossils (performed every $10 \mathrm{~cm}$ ) revealed a single Emiliania huxleyi at $2.28 \mathrm{~m}$ b.s.f. in $23-$ GC1, which indicates that the sediments at this level are younger than MIS 6 (Backman et al., 2009). The basal sediments in 20-GC1 likely correlate with the uppermost section of coarser sediments in 22-PC1, 23-GC1 and 24-GC1 (Fig. 9).

\subsection{Interpretation of acoustic stratigraphy}

Based on the combined chirp, swath-bathymetry and sediment core data, a summary of the acoustic units and their interpretation is made. Unit 1 is interpreted as iceberg-scoured postglacial sediments overlying a sharp peneplained seafloor on the shallow shelf $(<100-150 \mathrm{~m})$. The interpretation of a thin postglacial unit is derived from the dating of core 20GC1. Unit 2 is only visible on the shallow shelf and is interpreted as outcropping sedimentary or bedrock strata of unknown age and composition.

Unit 1 thickens in deeper water depths where it incorporates preglacial and glacial sediments reworked by sea level lowering during the last glacial cycle (Fig. 4). The depth of reworking in response to sea level lowering lies between 260 and $300 \mathrm{~m}$ b.s.1. Below this depth, Unit 1 gradually merges with Unit 3, which can then be traced as a continuous acoustically laminated unit extending seaward of the shelf break and downslope to water depths of $>2000 \mathrm{~m}$ b.s.l. (Fig. 4). Unit 3 is less affected by iceberg scouring than Unit 1 . The base of this acoustic unit corresponds to the diamicton (sedimentary Unit B) in cores 22-PC, 23-GC and 24-GC. Based on the relatively low shear strength and occurrence of foraminifera, these sediments are not interpreted as subglacial in origin (a till) but rather as a melt out or iceberg-rafted diamicton (Dowdeswell et al., 1994). Radiocarbon dates from 23-GC 

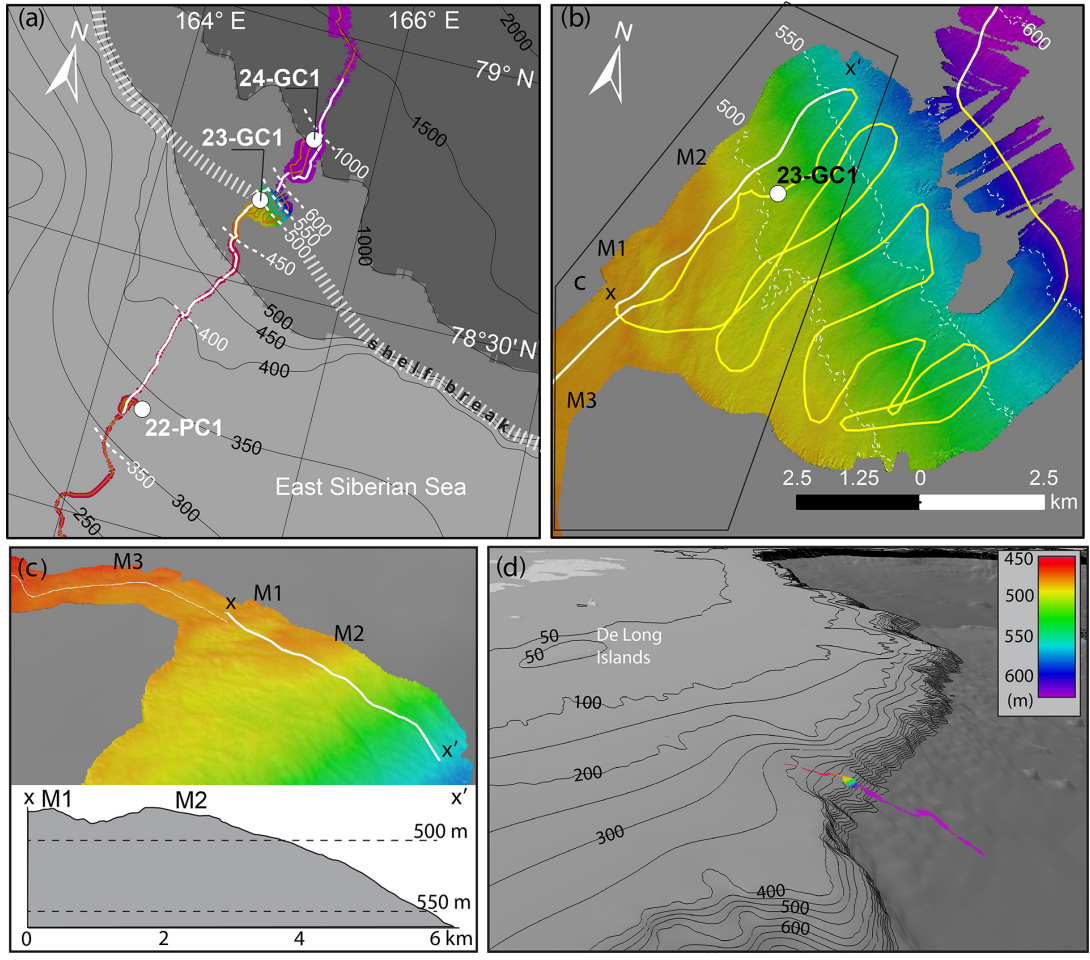

Figure 7. Multibeam mapping results. (a) Ship track and extent of mapping in the study area. Measured depths (white numbers and dashed lines) are shown in comparison with gridded depths in IBCAO. (b) Surveyed region on the outer shelf where the sedimentary mounds (grounding zone deposits) (M1, M2 and M3) are identified in the sub-bottom data. (c) Oblique view and bathymetric cross section of the interpreted grounding zone deposits (d) Oblique view of the outer East Siberian shelf with the De Long Islands and New Siberian Islands in the upper left. Multibeam data are overlain on IBCAO.

and 24-GC indicate that the diamicton was deposited prior to $46300 \pm{ }_{2600}^{3500} \mathrm{cal}$ years BP (Fig. 9). This date supports the interpretation that the base of Unit 3 incorporates preglacial and glacial sediments.

The acoustically transparent Unit 4 , is interpreted as subglacially deposited sediment (till). It can be traced laterally to the shelf break, where it forms two prominent sedimentary mounds oriented transverse to the track profile. These mounds are evident in the bathymetry data (Fig. 7) and extend laterally beyond the surveyed regions, exceeding widths of $\sim 10 \mathrm{~km}$. These sedimentary mounds are interpreted as grounding line deposits based on their position close to the shelf break, mounded geometry, steeper seaward facing slopes (M1 and M2) and the acoustically transparent to chaotic internal structure commonly seen in subglacial sediments (Dowdeswell et al., 2016). A second till facies (acoustic Unit 5) exists below Unit 4 and is separated by a commonly strong, planar reflector (R3). A third sedimentary mound (M3) is identified within this underlying till sequence. It is also interpreted as a grounding line deposit and formed before the latest ice advance that deposited M1 and M2.

The wedge-shaped acoustically transparent Unit 6 , found at the shelf break and separating the two till sequences, is interpreted as either a mass wasting deposit or an ice-proximal fan (Dowdeswell et al., 2016), deposited in front of the ice margin between the advances that formed M3 and M1/2. Downslope, the acoustically laminated sediments forming Unit 3 drape a $>65 \mathrm{~m}$ thick sequence of stacked, lenticular, acoustically transparent units (Fig. 6). These are interpreted as glacio-genic debris flows, composed of subglacial sediments delivered to the shelf edge (Elverhøi et al., 1997; Laberg and Vorren, 1995; Taylor et al., 2002). Laterally discontinuous lenses of acoustically transparent sediment are interpreted as downslope deposits, originating from mass wasting on the upper slope. The occurrence of acoustically laminated intervals within the sediment indicates periods of icedistal sedimentation, when glacial ice retreated from the shelf break.

\section{Discussion}

\subsection{The De Long Trough}

\subsubsection{Overview}

The geophysical data collected from the outer shelf and slope of the East Siberian Sea, north of the De Long Islands, are sparse but contain evidence for many elements commonly associated with a CST. These include grounding line deposits 

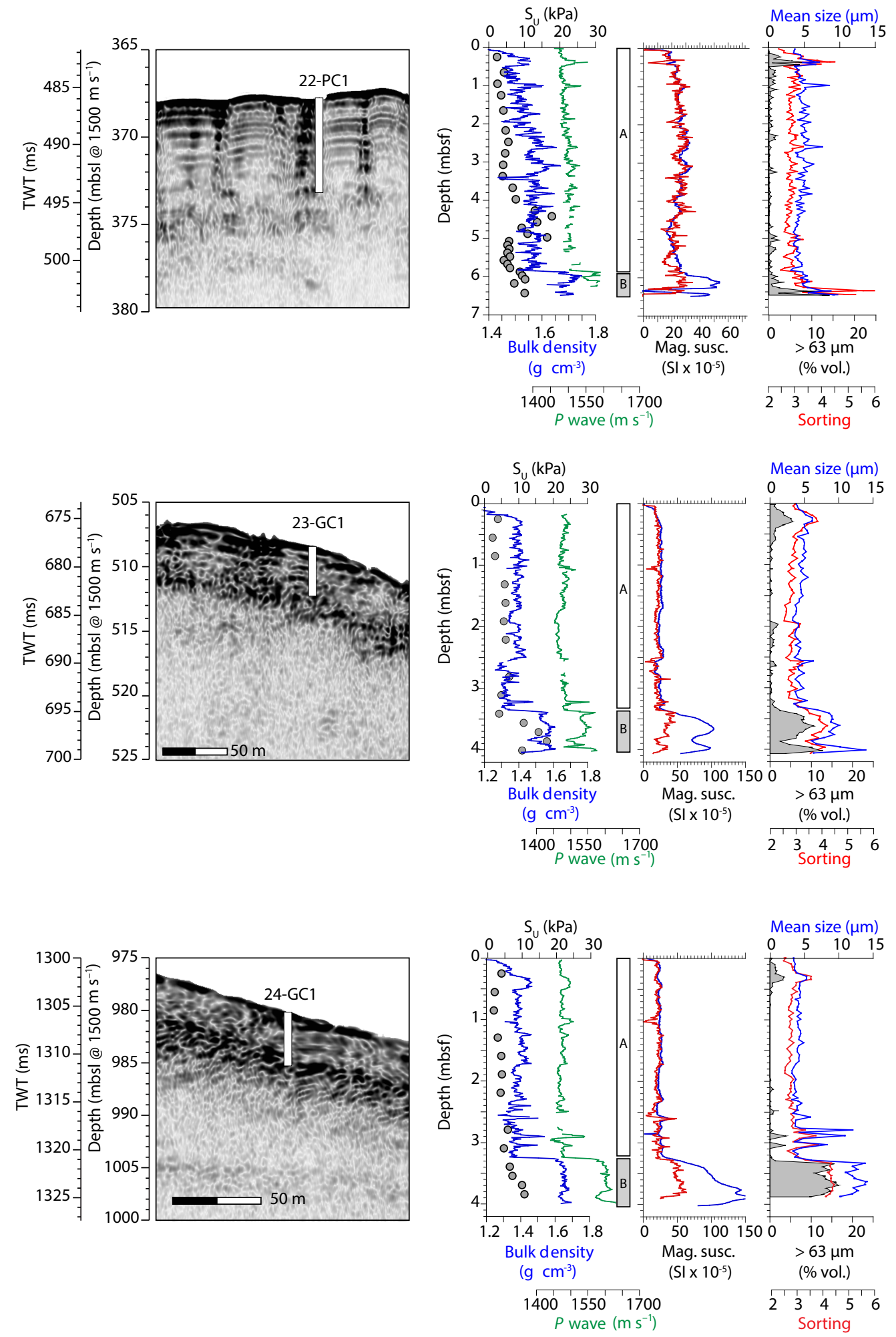

Figure 8. Detailed view of sub-bottom data, penetration and physical property measurements of cores 22-PC1, 23-GC1 and 24-GC1. All cores penetrate down to a strong reflector that marks the top of an acoustically transparent interval. The base of all the cores recovered a coarser-grained, poorly-sorted unit displaying a higher bulk density and magnetic susceptibility. This is interpreted as a diamict. 

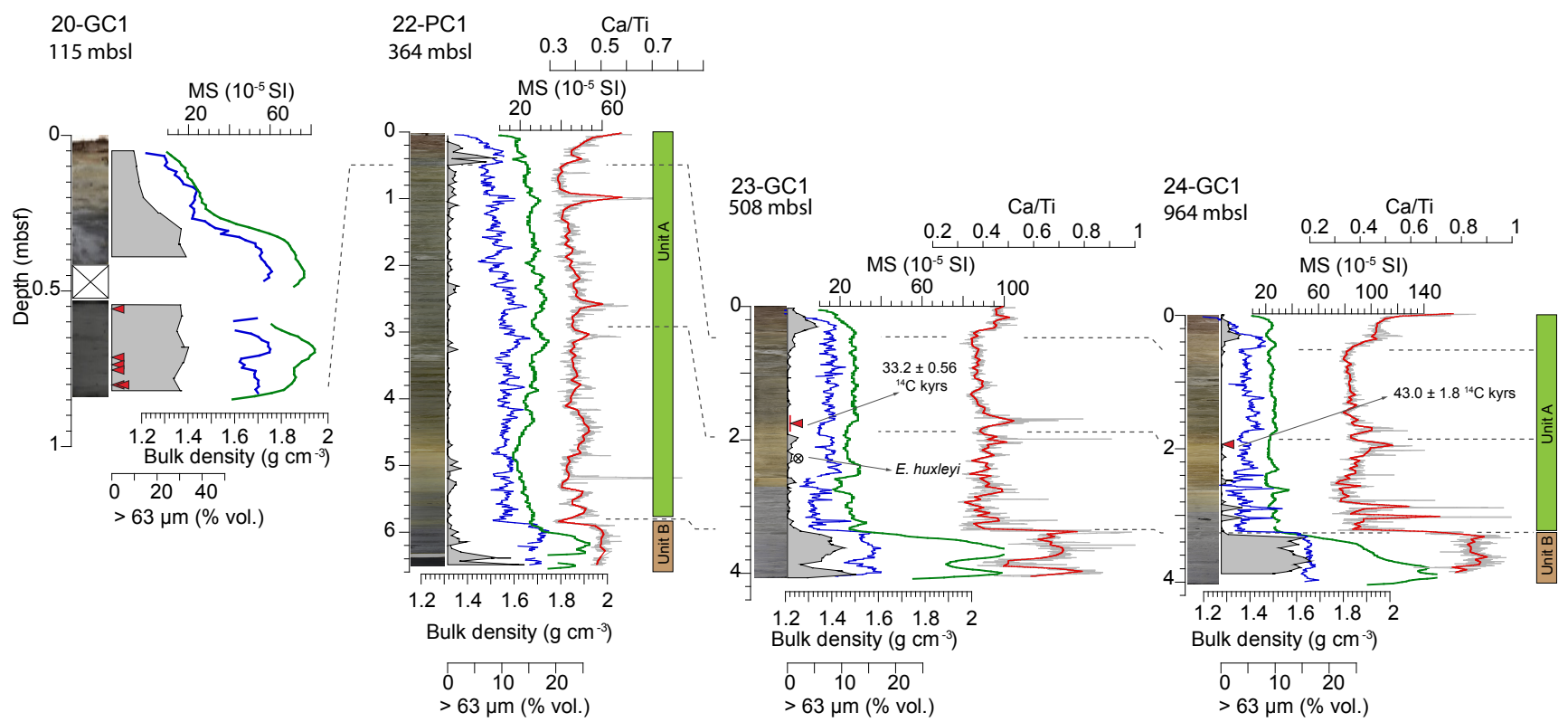

Figure 9. Stratigraphic correlation of core 20-GC1, 22-PC1, 23-GC1 and 24-GC1, based on MSCL, XRF-scanning, digital images and radiocarbon dating results. The acoustically laminated sediments of Unit 3 (Figs. 4 and 5) are represented by sedimentary Unit A in cores 22-PC1, 23-GC1 and 24-GC1. These undisturbed sediments overlie the glacial diamict of Unit B, which corresponds to acoustic Unit 4. The base of Unit A is older than $\sim 50 \mathrm{cal} \mathrm{kyr} \mathrm{BP}$ based on results from radiocarbon dating. Core 20-GC1 was obtained from $115 \mathrm{~m}$ b.s.1. It was taken from an area of the shelf that would have been exposed during the last glacial cycle. Radiocarbon dates from below $55 \mathrm{~cm}$ in the core indicate a deglacial age for the lowermost sediments. These likely correlate with the slightly coarser-grained interval seen in the upper few decimeters of cores 22-PC1, 23-GC1 and 24-GC1.

found near the shelf break in a pronounced bathymetric depression that extends landward for more $100 \mathrm{~km}$, seaward of which lies a recognizable TMF. This provides the first evidence for a CST on the Siberian shelf that we hereafter refer to as the De Long Trough. The dimensions of the De Long Trough and associated glacio-genic features are comparable to those from other Arctic glacial troughs recently compiled by Batchelor and Dowdeswell $(2014,2015)$ and are discussed in the following subsections.

\subsubsection{Grounding line deposits}

The limited mapping of the interpreted grounding line deposits makes the absolute discrimination between M1 and M2 uncertain, as is their interpretation as either GZWs or terminal moraines (Fig. 7). For example, the outermost sedimentary mound (M2), which is mapped in most detail, displays pronounced lateral variations in thickness (Fig. 7) that may more closely resemble a series of terminal moraines than a GZW (Batchelor and Dowdeswell, 2015). On the other hand, length-to-height ratios of all the sedimentary mounds range between $165: 1(5 \mathrm{~km} \times 30 \mathrm{~m})$ and $600: 1$ $(15 \mathrm{~km} \times 25 \mathrm{~m})$, commensurate with the subdued shape of GZWs compared to the lower length-to-height ratios commonly found in terminal or recessional moraines $(<10: 1)$ (Batchelor and Dowdeswell, 2015). The dimensions of these features (10-15 km long and 24-32 m high) are also com- parable to the majority of high-latitude GZWs, which tend to be less than $15 \mathrm{~km}$ long and $15-100 \mathrm{~m}$ thick (Batchelor and Dowdeswell, 2015). The grounding line deposits in the De Long Trough compare with smaller GZWs found in the northern and western Barents Sea, northwestern Greenland, Antarctica and the Mackenzie Trough in the Canadian Beaufort Sea (Batchelor and Dowdeswell, 2015).

As both GZWs and terminal moraines are grounding line deposits, either interpretation supports the more general conclusion that an ice sheet existed on the outer East Siberian continental shelf. However, as terminal moraines are commonly associated with deposition beneath slowly retreating ice margins, while GZWs are associated with stillstands in fast-streaming ice, the existing data are not capable of unambiguously describing retreat dynamics of the grounded ice. The absence of other diagnostic features for fast-streaming ice (i.e., MSGL), further adds to this ambiguity. However, we cannot rule out the possibility that streamed-lined trough parallel lineations may exist in this region but were simply not captured due to the limited extent of mapping.

\subsubsection{Cross-shelf trough}

The location of the grounding line deposits within a broad bathymetric depression that ends at the shelf break, suggests that they are features preserved within a glacially excavated trough. This trough can be identified in IBCAO Ver- 
sion 3.0 (Jakobsson et al., 2012b) (Fig. 3). In this area IBCAO is completely based on digitized contours from the Russian bathymetric maps published by the Head Department of Navigation and Oceanography (HDNO) in 1999 and 2001 (Naryshkin, 1999, 2001). The source data of the Russian HDNO maps are not publicly available. Given the broad similarity between our mapping results and those portrayed in IBCAO V. 3.0, the identified glacial features in the subbottom data, and the more detailed mapping of the grounding line formations near the shelf break, there is no reason to believe that a glacially scoured bathymetric trough is overinterpreted from the source data.

At the same time, bathymetric mapping during SWERUSC3 does reveal substantial differences in water depth compared to IBCAO Version 3.0 (Fig. 7a). Results from mapping indicate a lower gradient along the base of the trough between 400 and $500 \mathrm{~m}$ b.s.l., where the grounding line deposits are mapped, and a steeper slope beyond them, between 500 and $1000 \mathrm{~m}$ b.s.l. The dimensions of the De Long Trough at the shelf break, derived from IBCAO, are between 40 and $70 \mathrm{~km}$ wide, with a depth of $140 \mathrm{~m}$ (Fig. 3). The true depth at the shelf break is closer to $100 \mathrm{~m}$ given the new mapping data (Fig. 7a). Although many of the larger Antarctic CSTs and some found off southern Greenland deepen landward, there is no evidence of a reverse gradient within the De Long Trough. This is similar to other high Arctic CSTs in the Barents and Kara seas (Batchelor and Dowdeswell, 2014).

The dimensions of 75 Arctic CSTs, reviewed by Batchelor and Dowdeswell (2014), have modal lengths of 150$200 \mathrm{~km}$ (with more than $50 \%$ of them being between 50 and $200 \mathrm{~km}$ ), widths of $20-40 \mathrm{~km}$ and depths of $300-400 \mathrm{~m}$. Batchelor and Dowdeswell (2014) suggest that trough width and length are controlled by the volume of ice and sediment flowing through it, which depends on drainage basin size and the duration/number of times that a paleo-ice stream was active. Conversely, trough depths are more variable and probably controlled by the number of past glaciations, the underlying geology and the tectonic setting. Although the length of the interpreted trough is not accurately defined by the new mapping data (Fig. 3), the distance between 22-PC1 and $23-\mathrm{GCl}$ is $105 \mathrm{~km}$ and provides a minimum estimate for its length. Its width $(40-70 \mathrm{~km})$ falls within the modal range of other Arctic troughs, while its depth $(100-140 \mathrm{~m})$ is substantially shallower than any recognized Arctic CSTs. Additional bathymetric mapping is required to generate a more accurate and complete representation of the trough dimensions and the glacial features within it.

\subsubsection{Trough mouth fan}

TMFs are formed when fast-streaming ice delivers large volumes of subglacial sediments to the shelf edge, which is then remobilized and forms a stacked sequence of glaciogenic debris flows (Elverhøi et al., 1997; Laberg and Vorren, 1995; Taylor et al., 2002; Batchelor and Dowdeswell,
2014). The acoustic stratigraphy and morphology of the continental slope seaward of the grounding line deposits is typical of TMF sediments described on other high-latitude continental margins (Ó Cofaigh et al., 2003; Dowdeswell et al., 2016; Batchelor and Dowdeswell, 2014). The laterally discontinuous lenses of acoustically transparent material are glacio-genic debris flows and are interspersed with segments of acoustically laminated sediments, deposited when the ice stream retreated from the shelf edge.

Trough mouth fans can usually be identified in generalized bathymetric charts by a bulge in bathymetric contours along the continental slope, and a similar morphology is evident in IBCAO V. 3.0 seaward of the De Long Trough (Fig. 3). TMFs commonly approach areas of $10^{3}-10^{5} \mathrm{~km}^{2}$ and are most pronounced on shallow continental slopes $\left(<4^{\circ}\right)$ (Ó Cofaigh et al., 2003; Dowdeswell et al., 2016). The TMF in front of the De Long Trough has an average slope angle of $1.2^{\circ}$ and is steeper above $1300 \mathrm{~m}$ b.s.l. $\left(1.6^{\circ}\right)$ than below $\left(0.95^{\circ}\right)$. The area interpreted as a TMF (Fig. 3) totals $6540 \mathrm{~km}^{2}$. Sub-bottom data do not penetrate to the base of the glacio-genic debris flow sequence, which is greater than $65 \mathrm{~m}$ thick (90 ms TWT).

\subsection{Timing and association with ice sheets on the Siberian shelf}

The radiocarbon date from 24-GC indicates that the last episode of glacial activity in the De Long Trough occurred before $46300 \pm_{2600}^{3500}$ cal years BP (Table 2). This is supported by the date in 23-GC1 and the occurrence of E. huxleyi at $2.28 \mathrm{~m}$ b.s.f. in $23-\mathrm{GC} 1$, indicating that sediments overlying the glacial features are younger than MIS $6(\sim 130 \mathrm{ka})$. This implies that glacial ice did not occupy the De Long Trough during peak global ice volumes (MIS 2, 14-29 ka) of the last glacial cycle (MIS 2-4, 14-71 ka). The age constraints from this study place the occupation of glacial ice in the trough either during MIS $4(57-71 \mathrm{ka})$, a stadial during MIS 5 or during the penultimate glaciation (MIS 6, 130-191 ka).

The absence of glacial ice during the LGM is consistent with the existence of permafrost across much of the submarine East Siberian shelf (Romanovskii et al., 2004; Nicolsky et al., 2012), the reported absence of ice on Wrangel island during the LGM (Gaultieri et al., 2005) and the comparatively limited extent of the Kara ice sheet on the Barents Sea (Möller et al., 2015). The lack of glacial ice in the East Siberian Sea and the Kara Sea during the LGM are both ascribed to generally arid conditions due to a reduction in atmospheric moisture supply to these regions (Gaultieri et al., 2005; Möller et al., 2015). Glacial landforms indicating ice flow from the East Siberian shelf that are mapped on the continental slope of the East Siberian Sea, Arlis Plateau and southern Lomonosov Ridge were also formed prior to the LGM (Niessen et al., 2013; Jakobsson et al., 2016) and are consistent with the absence of glacial ice in the De Long Trough during this time. 
The De Long Trough notably connects to the reconstructed ice extents around the De Long and New Siberian Islands (Basilyan et al., 2008, 2010) (Fig. 1). Therefore, it is reasonable to assume that glacial activity in the trough is associated with known glaciations of the New Siberian Islands. Uranium-thorium $\left({ }^{230} \mathrm{Th} /{ }^{234} \mathrm{U}\right)$ dating of mollusk shells from undeformed Quaternary marine sediments overlying relict glacial sheet ice on the New Siberian Islands implies that glaciation was older than $84.7(-6.2 /+6.6) \mathrm{ka}$ (Basilyan et al., 2008, 2010). This age is supported by radiocarbon dates from mammal bones obtained from continental sediments above the marine deposits, which returned an oldest date of $48.6 \pm 1.5{ }^{14} \mathrm{C}$ kyr (Basilyan et al., 2008, 2010). These results suggest that glacial ice was not present on this region of the shelf during MIS 4 (57-71 ka). In fact, considering the influence of the rejuvenation of uranium by groundwater flow, Basilyan et al. $(2008,2010)$ argue that the true age of the marine mollusks is closer to $135 \mathrm{ka}$, coinciding with the end of MIS 6. An MIS 6 ice stream occupying the De Long Trough is consistent with age constraints provided in this study and would fit into the larger picture of an extensive Arctic ice shelf that was fed, in part, by glacial ice on the East Siberian shelf (Jakobsson et al., 2016). This would include an ice stream within the De Long Trough that fed a floating ice shelf from the grounding line.

The current data do not allow us to dismiss the possibility that a smaller local ice cap developed over the De Long Islands and fed an ice stream in the De Long Trough during a stadial of MIS 5. Late Quaternary glacial extents in the Kara Sea, specifically over the Taimyr Peninsula and the Severnaya Zemlya archipelago, were considerably larger during MIS 5d (109 ka) and 5b (87 ka), compared to the MIS 4 and LGM extents (Möller et al., 2015). However, when considering the most recent estimates for the age of glacial ice on the New Siberian islands (Basilyan et al., 2008, 2010) and the date of deep-water glacial features that indicate ice flow directions from the East Siberian shelf (Jakobsson et al., 2016), the most plausible explanation is that an ice stream was active in the De Long Trough during MIS 6. Additional research needs to focus on (1) establishing the connection between glacial ice in the De Long Trough and the existence of a larger ice sheet that covered much of the East Siberian shelf (Fig. 1) and (2) acquiring more detailed dating of the sedimentary sequences overlying the glacial deposits to determine if ice reoccupied the trough during a stadial of MIS 5.

\subsection{Sea level variations and sedimentation on the continental slope}

One of the remarkable observations based on the stratigraphy of sediment cores 22-PC1, 23-GC1 and 24-GC1 is that there does not appear to be a dramatic increase in sediment delivery to the outer shelf and slope during the last glacial cycle. This is despite fluctuating eustatic levels that would have seen the repeated exposure and flooding of the shelf. This is at odds with observations in the river-dominated Laptev Sea (Bauch et al., 2001) and the generally inferred influx of sediments to the outer shelf and slope during periods of transgression (Wegener et al., 2015). Reworking of sediments above $\sim 260 \mathrm{~m}$ b.s.l. is evidenced in the sub-bottom data (Acoustic Unit 1 sediments being reworked by sea level transgression) (Fig. 4), but little to no influence is seen in deeper sections. Therefore, the acoustically transparent intervals found on the continental slope in front of the De Long Trough (Fig. 6) and described further east in Parasound data from the East Siberian slope (Niessen et al., 2013) are not a consequence of eustatic sea level variations but originate from glacial activity on the shelf.

\section{Conclusions}

Geophysical and sediment coring data collected on Leg 2 of the 2014 SWERUS-C3 expedition reveal a set of grounding line deposits at the shelf break of the East Siberian Sea that lie within a distinct bathymetric depression interpreted as a glacial trough. This provides the first evidence for a glacially excavated trough on the East Siberian continental shelf and direct evidence for an ice sheet on the Siberian shelf. The dimensions of the grounding line deposits and glacial trough conform to the dimensions on the smaller Arctic cross-shelf troughs and the grounding zone wedges mapped within them. A thick sequence of glacio-genic debris flows exist seaward of the grounding line deposits and form a notable trough mouth fan. The ice stream occupying the trough was likely connected to glacial ice over the De Long and New Siberian Islands. Multiple lines of evidence indicate that the trough was occupied by an ice stream during the penultimate glaciation (MIS 6).

Data availability. Data shown in the article acquired during the SWERUS-C3 expedition in 2014 are available through the Bolin Centre for Climate Research database: http://bolin.su.se/data/ ORegan-2017 (Bolin Centre for Climate Research, 2017).

Competing interests. The authors declare that they have no conflict of interest.

Special issue statement. This article is part of the special issue "Climate-carbon-cryosphere interactions in the East Siberian Arctic Ocean: past, present and future (TC/BG/CP/OS inter-journal SI)". It is not associated with a conference.

Acknowledgements. We thank the supporting crew and Captain of I/B Oden and the support of the Swedish Polar Research Secretariat. Many thanks to Carina Johansson of the Department of Geological Sciences, Stockholm University, for laboratory assistance. This research and expedition was supported by the Knut 
and Alice Wallenberg Foundation (KAW). Individual researchers received support from the Swedish Research Council (Jan Backman 2013-5779; Martin Jakobsson 2012-1680; Matt O'Regan 2012-3091; Christian Stranne 2014-478), the U.S. National Science Foundation (Larry A. Mayer, PLR-1417789), US Geological Survey Climate \& Land Use R\&D Program (Thomas M. Cronin and Laura Gemery) and the Russian Government (Igor Semiletov: grant no. 14.Z50.31.0012). Christof Pearce received funding from the Danish Council for Independent Research, Natural Sciences (DFF-4002-00098_FNU). Any use of trade, firm or product names is for descriptive purposes only and does not imply endorsement by the U.S. Government.

Edited by: Carlo Barbante

Reviewed by: two anonymous referees

\section{References}

Anderson, J. B., Shipp, S. S., Lowe, A. L., Wellner, J. S., and Mosola, A. B.: The Antarctic Ice Sheet during the Last Glacial Maximum and its subsequent retreat history: a review, Quaternary Sci. Rev., 21, 49-70, https://doi.org/10.1016/S02773791(01)00083-X, 2002.

Backman, J., Fornaciari, E., and Rio, D.: Biochronology and paleoceanography of late Pleistocene and Holocene calcareous nannofossil abundances across the Arctic Basin, Mar. Micropaleontol., 72, 86-98, 2009.

Basilyan, A., Nikol'skyi, P., and Anisimov, M.: Pleistocene glaciation of the New Siberian Islands e no more doubt, IPY News, 12, 7-9, 2008.

Basilyan, A. E., Nikol'skyi, P. A., Maksimov, F. E., and Kuznetsov, V. Y.: Age of Cover Glaciation of the New Siberian Islands Based on 230Th/U-dating of Mollusk Shells, in: Structure and Development of the Lithosphere, Paulsen, Moscow, 506-514, 2010.

Batchelor, C. L. and Dowdeswell, J. A.: The physiography of High Arctic cross-shelf troughs, Quaternary Sci. Rev., 92, 6896, https://doi.org/10.1016/j.quascirev.2013.05.025, 2014.

Batchelor, C. L. and Dowdeswell, J. A.: Ice-sheet grounding-zone wedges (GZWs) on high-latitude continental margins, Mar. Geol., 363, 65-92, https://doi.org/10.1016/j.margeo.2015.02.001, 2015.

Bauch H. A., Kassens H., Naidina O. D., Kunz-Pirrung M., and Thiede J.: Composition and flux of Holocene sediments on the eastern Laptev Sea shelf, Arctic Siberia, Quaternary Res., 55, 344-351, 2001.

Blott, S. J. and Pye, K.: GRADISTAT: A grain size distribution and statistics package for the analysis of unconsolidated sediments, Earth Surf. Proc. Land., 26, 1237-1248, https://doi.org/10.1002/esp.261, 2001.

Bolin Centre for Climate Research: Marine sediment core data from De Long Trough, Siberian margin and slope, Arctic Ocean, Bolin Centre Database, Bolin Centre for Climate Research, Stockholm University, available at: http://bolin.su.se/ data/ORegan-2017, last access: 19 September 2017.

Clark, C. D.: Mega-scale glacial lineations and crosscutting ice-flow landforms, Earth Surf. Proc. Land., 18, 1-19, 1993.

Colleoni, F., Kirchner, N., Niessen, F., Quiquet, A., and Liakka, J.: An East Siberian ice shelf during the Late Pleistocene glacia- tions: Numerical reconstructions, Quaternary Sci. Rev., 147, 148-163, https://doi.org/10.1016/j.quascirev.2015.12.023, 2016.

Cronin, T. M., O’Regan, M., Pearce, C., Gemery, L., Toomey, M., Semiletov, I., and Jakobsson, M.: Deglacial sea level history of the East Siberian Sea and Chukchi Sea margins, Clim. Past, 13, 1097-1110, https://doi.org/10.5194/cp-13-1097-2017, 2017.

Dove, D., Polyak, L., and Coakley, B.: Widespread, multi-source glacial erosion on the Chukchi margin, Arctic Ocean, Quaternary Sci. Rev., 92, 112-122, 2014.

Dowdeswell, J. A., Whittington, R. J., and Marienfeld, P.: The origin of massive diamicton facies by iceberg rafting and scouring, Scoresby Sund, East Greenland, Sedimentology, 41, 21-35, 1994.

Dowdeswell, J. A., Canals, M., Jakobsson, M., Todd, B. J., Dowdeswell, E. K., and Hogan, K. A.: The variety and distribution of submarine glacial landforms and implications for icesheet reconstruction, Geological Society, London, Memoirs, 46, 519-552, https://doi.org/10.1144/M46.183, 2016.

Elverhøi, A., Norem, H., Andersen, E. S., Dowdeswell, J. A., Fossen, I., Haflidason, H., Kenyon, N. H., Laberg, J. S., King, E. L., Sejrup, H. P., Solheim, A., and Vorren, T.: On the origin and flow behaviour of submarine slides on deep-sea fans along the Norwegian-Barents Sea continental margin, Geo-Mar. Lett., 17, 119-125, 1997.

Engels, J. L., Edwards, M. H., Polyak, L., and Johnson, P. D.: Seafloor evidence for ice shelf flow across the Alaskan Beaufort margin of the Arctic Ocean, Earth Surf. Proc. Land., 32, 1-17, 2008.

Grosswald, M. G.: An ice sheet on the East Siberian shelf in the late Pleistocene, Polar Geography and Geology, 14, 294-304, https://doi.org/10.1080/10889379009377442, 1990.

Gualtieri, L., Vartanyan, S. L., Brigham-Grett, J., and Anderson, P. M.: Evidence for an ice-free Wrangel Island, northeast Siberia during the Last Glacial Maximum, Boreas, 34, 264-273, https://doi.org/10.1111/j.1502-3885.2005.tb01100.x, 2005.

Hogan, K. A., Dowdeswell, J. A., Noormets, R., Evans, J., Ó Cofaigh, C., and Jakobsson, M.: Submarine landforms and ice-sheet flow in the Kvitøya Trough, northwestern Barents Sea, Quaternary Sci. Rev., 29, 3545-3562, 2010.

Hogan, K. A., Ó Cofaigh, C., Jenninges, A. E., Dowdeswell, J. A., and Hiemstra, J. F.: Deglaciation of a major palaeo-ice stream in Disko Trough, West Greenland, Quaternary Sci. Rev., 147, 5-26, https://doi.org/10.1016/j.quascirev.2016.01.018, 2016.

Hughes, T. J., Denton, G. H., and Grosswald, M. G.: Was there a late-Würm Arctic ice sheet?, Nature, 266, 596-602, 1977.

Jakobsson, M.: Submarine glacial landform distribution in the central Arctic Ocean shelf-slope-basin system, Geological Society, London, Memoirs, 46, 469-476, https://doi.org/10.1144/M46.179, 2016.

Jakobsson, M., Nilsson, J., O’Regan, M., Backman, J., Löwemark, L., Dowdeswell, J. A., Colleoni, F., Marcussen, C., Anderson, L., Björk, G., Darby, D., Eriksson, B., Hanslik, D., Hell, B., Mayer, L., Polyak, L., Sellén, E., and Wallin, Å.: An Arctic Ocean ice shelf during MIS 6 constrained by new geophysical and geological data, Quaternary Sci. Rev., 29, 3505-3517, https://doi.org/10.1016/j.quascirev.2010.03.015, 2010.

Jakobsson, M, Anderson, J. B., Nitsche, F., Gyllencreutz, R., Kirchner, A., Kirchner, N., O'Regan, M., Mohammad, R., and Eriksson, B.: Ice sheet dynamics inferred 
from glacial morphology of the central Pine Island Bay Trough, West Antarctica, Quaternary Sci. Rev., 38, 1-10, https://doi.org/10.1016/j.quascirev.2011.12.017, 2012a.

Jakobsson, M., Mayer, L. A., Coakley, B., Dowdeswell, J. A., Forbes, S., Fridman, B., Hodnesdal, H., Noormets, R., Pedersen, R., Rebesco, M., Schenke, H.-W., Zarayskaya, Y., Accettella, A. D., Armstrong, A., Anderson, R. M., Bienhoff, P., Camerlenghi, A., Church, I., Edwards, M., Gardner, J. V., Hall, J. K., Hell, B., Hestvik, O. B., Kristoffersen, Y., Marcussen, C., Mohammad, R., Mosher, D., Nghiem, S. V., Pedrosa, M. T., Travaglini, P. G., and Weatherall, P.: The International Bathymetric Chart of the Arctic Ocean (IBCAO) Version 3.0, Geophys. Res. Lett., 39, L12609, https://doi.org/10.1029/2012GL052219, 2012b.

Jakobsson, M., Andreassen, K., Bjarnadóttir, L. R., Dove, D., Dowdeswell, J. A., England, J. H., Funder, S., Hogan, K., Ingólfsson, Ó., Jennings, A., Larsen, N. K., Kirchner, N., Landvik, J. Y., Mayer, L., Mikkelsen, N., Möller, P., Niessen, F., Nilsson, J., O'Regan, M., Polyak, L., Nørgaard-Pedersen, N., and Stein, R.: Arctic Ocean glacial history, Quaternary Sci. Rev., 92, 40-67, https://doi.org/10.1016/j.quascirev.2013.07.033, 2014.

Jakobsson, M., Nilsson, J., Anderson, L., Backman, J., Björk, G., Cronin, T. M., Kirchner, N., Koshurnikov, A., Mayer, L., Noormets, O’Regan, M., Stranne, C., Ananiev, R., Macho, N. B., Chernykh, D., Coxall, H. K., Eriksson, B., Flodén, T., Gemery, L., Gustafsson, Ö., Jerram, K., Johansson, C., Khortov, A., Mohammad, R., and Semiletov, I. R.: Evidence for an ice shelf covering the central Arctic Ocean during the penultimate glaciation, Nature Communications, 7, 10365, https://doi.org/10.1038/ncomms10365, 2016.

King, E. C., Hindmarch, R. C. A., and Stokes, C. R.: Formation of mega-scale glacial lineations observed beneath a West Antarctic ice stream, Nature Geosci., 2, 585-588, 2009.

Kirshner, A. E., Anderson, J. B., Jakobsson, M., O’Regan, M., Majewski, W., and Nitsche, F. O.: Post-LGM deglaciation in Pine Island Bay, West Antarctica, Quaternary Sci. Rev., 38, 11-26, https://doi.org/10.1016/j.quascirev.2012.01.017, 2012.

Klemann, V., Heim, B., Bauch, H. A., Wetterich, S., and Opel, T.: Sea-level evolution of the Laptev Sea and the East Siberian Sea since the last glacial maximum, Arktos, 1, 1, https://doi.org/10.1007/s41063-015-0004-x, 2015.

Laberg, J. S. and Vorren, T. O.: Late Weichselian submarine debris flow deposits on the Bear Island Trough Mouth Fan, Mar. Geol., 127, 45-72, 1995.

Lambeck, K., Rouby, H., Purcell, A., Sun, Y., and Sambridge, M.: Sea level and global ice volumes from the Last Glacial Maximum to the Holocene, P. Natl. Acad. Sci. USA, 111, 15296-15303, 2014.

Möller, P., Alexanderson, H., Funder, S., and Hjort, C.: The Taimyr Peninsula and the Severnaya Zemlya archipelago, Arctic Russia: a synthesis of glacial history and palaeo-environmental change during the Last Glacial cycle (MIS 5e-2), Quaternary Sci. Rev., 107, 149-181, 2015.

Naryshkin, G.: Bottom relief of the Arctic Ocean, Russian Academy of Sciences, Bathymetric contour map, scale 1:5000 000, 1999.

Naryshkin, G.: Bottom relief of the Arctic Ocean, Russian Academy of Sciences, Bathymetric contour map, scale 1:2 500 000, 2001.

Nicolsky, D. J., Romanovsky, V. E., Romanovskii, N. N., Kholodov, A. L., Shakhova, N. E., and Semiletov, I. P.: Modeling sub-sea permafrost in the East Siberian Arctic Shelf:
The Laptev Sea region, J. Geophys. Res., 117, F03028, https://doi.org/10.1029/2012JF002358, 2012.

Niessen, F., Hong, J. K., Hegewald, A., Matthiessen, J., Stein, R., Kim, H., Kim, S., Jensen, L., Jokat, W., and Nam, S.: Repeated Pleistocene glaciation of the East Siberian continental margin, Nature Geosci., 6, 842-846, 2013.

Ó Cofaigh, Pudsey, C. J., Dowdeswell, J. A., and Morris, P.: Evolution of subglacial bedforms along a paleo-ice stream, Antarctic Peninsula continental shelf, Geophys. Res. Lett., 29, 41-1-41-4, https://doi.org/10.1029/2001GL014488, 2002.

Ó Cofaigh, C., Taylor, J., Dowdeswell, J. A., and Pudsey, C. J.: Palaeo-ice streams, trough mouth fans and high-latitude continental slope sedimentation, Boreas, 32, 37-55, 2003.

Ottesen, D. and Dowdeswell, J. A.: An inter-ice stream glaciated margin: submarine landforms and a geomorphic model based on marine-geophysical data from Svalbard, Geol. Soc. Am. Bull., 121, 1647-1665, 2009.

Ottesen, D., Dowdeswell, J. A., and Rise, L.: Submarine landforms and the reconstruction of fast-flowing ice streams within a large Quaternary ice sheet: the 2500-km-long Norwegian-Svalbard margin $\left(57^{\circ}\right.$ to $\left.80^{\circ} \mathrm{N}\right)$, Geol. Soc. Am. Bull., 117, 1033-1050, 2005.

Polyak, L., Forman, S. L., Herlihy, F. A., Ivanov, G., and Krinitsky, P.: Late Weichselian deglacial history of the Svyataya (Saint) Anna Trough, northern Kara Sea, Arctic Russia, Mar. Geol., 143, 169-188, https://doi.org/10.1016/S0025-3227(97)00096-0, 1997.

Polyak, L., Darby, D., Bischof, J., and Jakobsson, M.: Stratigraphic constraints on late Pleistocene glacial erosion and deglaciation of the Chukchi margin, Arctic Ocean, Quaternary Res., 67, 234 245, 2007.

Reimer, P. J., Bard, E., Bayliss, A., Beck, J. W., Blackwell, P. G., Bronk Ramsey, C., Grootes, P. M., Guilderson, T. P., Haflidason, H., Hajdas, I., Hatté, C., Heaton, T. J., Hoffmann, D. L., Hogg, A. G., Hughen, K. A., Kaiser, K. F., Kromer, B., Manning, S. W., Niu, M., Reimer, R. W., Richards, D. A., Scott, E. M., Southon, J. R., Staff, R. A., Turney, C. S. M., and van der Plicht, J.: IntCal13 and Marine13 Radiocarbon Age Calibration Curves 0-50,000 Years cal BP, Radiocarbon, 55, 1869-1887, https://doi.org/10.2458/azu_js_rc.55.16947, 2013.

Rohling, E. J., Foster, G. L., Grant, K. M, Marina, G., Roberts, A. P., Tamisiea, M. E., and Williams, F.: Sea-level and deep-seatemperature variability over the past 5.3 million years, Nature, 508, 477-482, https://doi.org/10.1038/nature13230, 2014.

Romanovskii, N. N., Hubberten, H. W., Gavrilov, A. V., Tumskoy, V. E., and Kholodov, A. L.: Permafrost of the east Siberian Arctic shelf and coastal lowlands, Quaternary Sci. Rev., 23, 1359-1369, 2004.

Stokes, C. R. and Clark, C. D.: Are long bedforms indicative of fast ice flow?, Boreas, 31, 239-249, 2002.

Taylor, J., Dowdeswell, J. A., Kenyon, N. H., and Ó Cofaigh, C.: Late Quaternary architecture of trough-mouth fans: debris flows and suspended sediments on the Norwegian margin, in: Glacier-Influenced Sedimentation on High-Latitude Continental Margins, edited by: Dowdeswell, J. A. and Ó Cofaigh, C., Geological Society, London, Special Publications, 203, 55-71, https://doi.org/10.1144/GSL.SP.2002.203.01.04, 2002.

Toll, E. V.: Fossil glaciers of the New Siberian Islands, their relationship to mammoth carcasses and to the glacial period, $\mathrm{Za}$ - 
piski Russkogo Geograficheskogo Obshchestva po obshchey geografii, 32, 1-139, 1897.

Wegner, C., Bennett, K. E., de Vernal, A., Forwick, M., Fritz, M., Heikkilä, M., Lacka, M., Lantuit, H., Laska, M., Moskalik, M., O’Regan, M., Pawłowska, J., Promińska, A., Rachold, V., Vonk, J. E., and Werner, K.: Variability in transport of terrigenous material on the shelves and the deep Arctic Ocean during the Holocene, Polar Res., 34, 24964, https://doi.org/10.3402/polar.v34.24964, 2015.
Winsborrow, M. C., Andreassen, K., Corner, G., and Laberg, J. S.: Deglaciation of a marine-based ice sheet: Late Weichselian palaeo-ice dynamics and retreat in the southern Barents Sea reconstructed from onshore and offshore glacial geomorphology, Quaternary Sci. Rev., 29, 424-442, https://doi.org/10.1016/j.quascirev.2009.10.001, 2010. 